\title{
SHARIAH AND HUMAN RIGHTS PERSPECTIVES ON INTERFAITH MARRIAGE: CHALLENGES IMPEDING ITS PRACTICE IN NIGERIA
}

\author{
Ibrahim Imam*
}

\begin{abstract}
Within the context of Nigeria, this paper investigates those principles of Shariah that regulate marriage, particularly interfaith union. This is with the goal of explicating certain limitations placed by Islam on the ability of Muslim women to marry non-Muslims. In particular, it is considered whether these limitations prejudice the right to freedom of religion guaranteed in the Nigerian Constitution. Ultimately, the paper establishes that marriage in Nigeria is usually solemnised in a manner reflective of the country's diversity. This investigation is motivated by the recent controversy surrounding the right of Nigerian Muslim women to enter into interfaith relationships. The paper uses a library-based, doctrinal research method to argue that there are several challenges associated with interfaith marriage in Nigeria, all resulting from the multi-cultural, multi-religious and multi-ethnic makeup of the country. It is concluded that, though interfaith marriages exist in Nigeria, parties entering into such marriages must agree on some salient issues in order to sustain conjugal bliss.
\end{abstract}

Keywords: Marriage, Interfaith, Shariah, Ahl-Kitab, Human Rights, Constitution.

\section{INTRODUCTION}

One of the contemporary issues affecting unity, peace, security and development in Nigeria is a spate of religious crises. Nigeria's two major religions, Islam and Christianity, do not trust each other in matters of everyday life, making religious conflict a permanent feature of the country. This perpetual conflict, religious intolerance, lack of cordiality, bitterness and gross animosity makes it difficult to discuss national unity, much less interfaith marriage between Muslims and Christians. The effect of this phenomenon accounts for the series of religious crises experienced in various cities of the country since independence in 1960, especially in the Northern states and some parts of Western Nigeria. Such sectarian crises were experienced during the Constitutional Drafting Committee (CDC) (1979), in Kano (1980, 1982, and 1991), when Nigeria joined the Organisation 
of the Islamic Council (OIC) (1986), and subsequently in cities like Katsina (1991), Kaduna (1987, 1988 and 1992), Maiduguri (1982), Yola (1984), Bauchi (1991), Zaria (1992), Zango Kataf (1992), Funtua (1993), Potiskum (1994)1, and Jos (2010). Most recently, the abduction of Christian Chibok School girls in Maiduguri (2010) and the current Boko Haram insurgency in the Northwest (1999 to the present) have blighted the country. ${ }^{2}$ These incidents have adversely affected inter-marriage between the adherents of the two major religions in Nigeria.

The notion of marriage as an inalienable right is universally acclaimed and protected. But be that as it may, insofar as marriage law is concerned, Nigeria has had no unified marriage law since its independence. The laws that regulate marriage in Nigeria are the Marriage Act, the Muslim Personal Law and Traditional/Customary Law, and which together take care of the three major religions in the country. ${ }^{3}$ In this perspective, English Law regulates marriage among persons who subject themselves to its jurisdiction, Islamic Marriage Law regulates marriage among Nigerian Muslims, and Customary Law applies to those who want to marry under the traditional system.

Under Islamic law, marriage is viewed as a civil contract freely entered into subject to certain conditions between a man and a woman in line with Islamic principles ${ }^{4}$ Although, Islam protects the rights of contracting parties, Shariah forbids any marriage that falls within a list of prohibited degrees, ${ }^{5}$ such as marriage between a man and his father's wife, mother, daughter, foster mother, foster sister, wife's mother, or step-daughters under his guardianship. ${ }^{6}$ By constrast, differences in tribe, ethnicity, race, religion, and economic status do not stand in the way of marriage.

Against the above background, this paper investigates the rights Nigerian Muslim women have to interfaith marriage and the challenges associated with the practice. To achieve this, the paper explores the extent to which Muslim women have the right to marry outside the Islamic faith. This investigation becomes imperative in view of the lingering acrimony between Muslims and Christians in Nigeria and because there is no direct Qur'anic or Sunnatic legislation that guarantees a woman's right to interfaith marriage.

\section{MARRIAGE AND ITS IMPORTANCE IN SHARIAH}

In Shariah, the Arabic term 'nikah' is used for marriage and means 'uniting'. In a more technical sense, it can also be construed as a contract ('aqd), ${ }^{7}$ ziwaj (pairing), ${ }^{8}$ sexual intercourse, ${ }^{9}$ marriage, ${ }^{10}$ or marriage and intercourse. ${ }^{11}$ Irrespective of the differences between these conceptions, marriage holds a unique position as a social phenomenon common to all human societies. In the 
Islamic context, it is especially important when discussing issues of satisfying sexual desire and procreation. ${ }^{12}$ Aside from this, it is a basic requirement for achieving a dignified existence and can be a source of joy and tranquility for both partners. ${ }^{13}$ As established in the Holy Quran: 'Among His signs is that He created for you mates from among yourselves, that you may dwell in tranquility with them and He has put love and mercy between your hearts and in that are signs for those who reflect.' 14

In Islam, the legitimacy of marriage depends on strict adherence to the principles of Shariah, irrespective of any constitutionally-guaranteed rights. ${ }^{15}$ While Jurists differ on their conception of marriage, according to the majority of Hanafi, Maliki, Hanbali and Zahiri scholars, and although marriage may be deemed supererogatory (' $u b a h$ ) for some, in most cases it is obligatory (wajib). Thus, in their view marriage is compulsory for a man who has: the means to pay a dower (mahr) and maintain both a wife and child; is healthy; and fears he may commit fornication (zina) if he remains unmarried. Likewise, these jurists maintain that it is also obligatory for a woman to marry if she has no means of maintaining herself or fears that her sexual desire may push her into fornication. By contrast, marriage is recommendatory (mandub) for a person who has strong control of his sexual desire and is unlikely to fall prey to evil temptation. ${ }^{16}$ According to the Shafi'i school of law, marriage is supererogatory for a person who can control his sexual desire, has no wish to have children or feels that marriage will keep him away from his devotion to Allah. ${ }^{17}$ The Prophet (pbuh) said, 'Oh you group of young men whoever among you is able to afford it let him get married, for verily it is better for lowering the gaze and proper for private part. ${ }^{18}$

Marriage is also a basis for organising relationships between couples and can act as a foundation for the exchange of rights and mutual assistance, thereby bringing about a circle of love, respect, affection and honour. ${ }^{19}$ There is a general consensus that marriage in Islam guarantees spiritual purity, protection from $\sin ^{20}$ and, by giving rise to the concept of the family, a foundation for a morally inclined community. ${ }^{21}$ Thus, a marriage contract deserves proper planning; otherwise, it may inevitably crash. ${ }^{22}$

However, marriage is a complex institution ${ }^{23}$ It is capable of bringing about a unique set of issues that those associated with it, including couples and their families, may have to contend with all their lives. ${ }^{24}$ This is particularly true within the multi-cultural, multi-religious and close-knit family system of Nigeria, which makes marriage more demanding than it is in (for example) the West. ${ }^{25}$ Indeed, the basic values that define this most important of relationships in Nigeria differ quite considerably from how the practice is understood in the Western world. ${ }^{26}$ 


\section{MARRIAGE AS AN INDIVIDUAL AND FUNDAMENTAL HUMAN RIGHT}

It is germane from the outset to begin by asking the following questions: Is there a constitutional right to marriage and what relationships are included within the right to marry? Does the fundamental right to marriage include the right to interfaith marriage?

It has been argued that the right to marry is a fundamental one, inherent to the liberty of the individual. In the United States, the Due Process and Equal Protec $\neg$ tion statute guarantees intending couples the right to marriage in general terms. Nigeria, like many other countries globally, is committed to the protection of individual rights and the rule of law. It is, however, and in view of the Shariah position, unclear whether such a right extends to a Muslim woman's right to interfaith marriage. ${ }^{27}$ Be that as it may, the Nigeria Constitution of 1999, under Chapter IV, provides the fundamental human rights to freedom of religion, practice and worship. ${ }^{28}$ Inferentially, and in so far as marriage is a religious obligation, these provisions not only guarantee a woman's rights to marriage, but also presupposes that they have the right to marry any person of their choice.

As under domestic constitutions, women's rights are also inherently guaranteed in international and regional agreements; this, mutatis mutandis, extends to women's freedom to marry any person of their choice, irrespective of religious affiliation. ${ }^{29}$ By implication therefore, any attempt to deny a woman her guaranteed rights would amount to discrimination and a violation of those rights. For instance, the Universal Declaration of Human Rights (UDHR), the Convention on Elimination of All Discrimination against Women (CEDAW), and the International Covenant on Social, Political and Cultural Rights (ICSPCR) define discrimination against women as any distraction, exclusion or restriction made on the basis of their sex..$^{30}$

The UDHR explicitly provides that men and women of full age, without any limitation due to race, nationality or religion, have the right to marry and to raise a family. They are entitled to equal rights to marriage, during marriage and at its dissolution. Moreover, marriage shall only be entered into with the free and full consent of the intending spouses. ${ }^{31}$ In the same paradigm, the International Covenant on Civil and Political Rights recognises the right of men and women of marriageable age to marry and to found a family, though such marriage shall not be entered into without the free and full consent of the intending spouses. ${ }^{32}$ The CEDAW enjoins state parties to take all appropriate measures to eliminate discrimination against women in all matters relating to marriage and family relations and to ensure, on a basis of equality with men, the same rights to enter freely into marriage and freely choose a spouse..$^{33}$ In the same vein, the Convention on the Elimination of Racial Discrimination (CERD) guarantees women's rights 
to marriage and choice of spouse irrespective of religious belief. ${ }^{34}$ Employing the human rights based approach, a careful perusal of these conventions enriches our understanding of women's right to interfaith marriage in society.

Regrettably, however, women's rights to interfaith marriage in Nigeria have consistently remained a complicated matter, especially amongst growing tensions and lack of trust between Muslims and Christians..$^{35}$ As such, there has been an alarming tendency by adherents of the two religions to discourage such unions. Recent examples of threats to inter-faith marriage include the abduction of 250 mostly Christian Chibok girls by the Islamic fundamentalist group Boko Haram and a series of attacks on Churches and Mosques. ${ }^{36} \mathrm{~A}$ similarly inhibiting factor threatening interfaith marriage is the recent protest by the Christian Association of Nigeria (CAN), Osun State Chapter, against the right of Muslim women to wear the headscarf (hijab) in public Secondary Schools. This follows the judgment of the Osun State High Court in Sheikh Salahudeen Ade Olayiwola \& Ors v. the Governor of Osun State \& $\mathrm{Ors}^{37}$ that the wearing of the hijab constitutes part of a Muslim woman's fundament right to freedom of religion under section 38 of the Nigerian Constitution 1999.

While friendships between the Muslims, Christians and other traditional religious minority populations are tolerated in Nigeria, romantic relations crossing the religious divide are not. Religious identification is important among today's Nigerians ${ }^{38}$ and can be used to legitimise discrimination by one religion against another in order to protect the former's own religious legacy. This identification has inadvertently extended into the realm of interfaith marriage among the adherents of various religious groups in Nigeria.

Today, fifty-six years after the birth of Nigeria as a sovereign nation, Islam and Christianity continue to routinely encounter irresolvable issues, of which interfaith marriage is one. ${ }^{39}$ These unfortunate scenarios are uncalled for and merely typify the lingering inhibiting factors to the acceptance of interfaith relations in Nigeria. This obstacle constitutes a serious threat to the relationships between Nigerians in general, but particularly for aspiring Muslims and nonMuslims alike who wish to enter into an interfaith marriage. ${ }^{40}$

\section{INTERFAITH MARRIAGE IN THE SHARIAH}

Some modern Islamic scholars and commentators have argued that the emergence of pluralistic modern societies and the impact of globalisation justify the need to re-evaluate the Shariah rules restricting or limiting women's rights to interfaith marriage. ${ }^{41}$ Obviously, many Islamic and Muslim-dominated countries like Nigeria face the challenges of modernity and rapid social change. ${ }^{42}$

Interfaith marriage can be defined in a number of ways. Most commonly, it 
is seen as a marriage wherein the partners belong to different faith groups (such as a Muslim married to Christian etc.). ${ }^{43}$ Zahidul Islam, for example, defines interfaith marriage as a marital union in which the partners believe and belong to different faiths or religious traditions. Sometimes, 'interfaith marriage' and 'mixed marriage' are used interchangeably, though a mixed marriage may also be equated with a marital union in which partners are of a different race or ethnicity but belong to the same faith. ${ }^{44}$

But regardless of the definition, the contractual nature of interfaith marriage and the mutual consent inherent to the marriage agreement between spouses remains. The spiritual conviction of the parties, however, may remain significant because it could mar the peace of the relationship, as outlined by the Prophet's wise counsel to Muslims:

Do not marry only for the sake of beauty; may be the beauty becomes the cause of moral degradation. Do not even marry even for the sake of wealth; may be the wealth becomes the reason of insubordination. Marry rather on the ground of religion devotion..$^{45}$

Indeed, people do tend to prefer marriage to those of the same religious status as themselves. Several other factors may also influence the decision, ${ }^{46}$ however, as outlined in this Prophetic tradition: "A woman is married for four things, i.e., her wealth, her family status, her beauty and her religion. So you should marry the religious woman (otherwise) you will be a loser. ${ }^{97}$

Importantly, regulation of interfaith marriage in the Shariah can be understood within the context of the exclusion of non-Muslims from the dynamics of society, especially through family law. ${ }^{48}$ This can be fathomed from the Qur'an:

O you, who believe, do not take the unbelievers for friends rather than the believers; do you desire that you should give to Allah a manifest proof against yourselves? ${ }^{49}$

In another verse, the Qur'an says:

O you, who believe, do not take My enemy and your enemy for friends: would you offer them love while they deny what has come to you of the truth, driving out the Apostle and yourselves because you believe in Allah, your Lord? If you go forth struggling hard in My path and seeking My pleasure, would you manifest love to them? And I know what you conceal and what you manifest; and whoever of you does this, he indeed has gone astray from the straight path. ${ }^{50}$

Arguably, many basic social and legal relationships, as well as the legal rights modeled within the framework of religious affiliation, can divide and derail social 
interactions between persons adhering to different religions. Under Islamic Law, religious differences affect many kinds of legal issues and the resolution of such legal cases will determine one's religious identity.

\subsection{Interfaith Marriage between a Male Muslim and Unbeliever}

In the Shariah, the rules regarding the rights of Muslim men to marry nonMuslim women differ from those pertaining to Muslim females. ${ }^{51}$ According to the Qur'an, the principles governing interfaith marriage between a Muslim male and non-Muslim female ${ }^{52}$ are as follows:

Do not marry the idolatresses till they believe, for a believing slave woman is better than an idolatress woman, even though she should please you. ${ }^{53}$

This day the good things are allowed to you... and so are the virtuous women of those who received the scripture before you (are lawful for you); when you have given them their marriage portion and live with them in honour, neither in fornicating nor taking as secret concubines. ${ }^{54}$

O you who believe!...when believing women come to you as fugitives, examine them. Allah is best aware of their faith. Then if you know them to be true believers, send them not back to the disbelievers. They are not lawful for them (the disbelievers), nor are they (the disbelievers) lawful for them..$^{55}$

These verses legally permit Muslim men to marry women from among the People of the Book (Christians and Jews), provided the women in question are virtuous. ${ }^{56}$ This is despite the fact that the People of the Book do not believe in Allah or that Muhammed is the last of the prophets. ${ }^{57}$ Though the People of the Book are followers of previous divine messages sent through Allah's messengers, their beliefs are distorted. ${ }^{58}$ It is essential to note, however, that while the above verses reveal Islam to be tolerant towards Muslim men marrying from among the People of the Book, they forbid interfaith marriage with polytheists, atheists and idol worshippers. ${ }^{59}$ The distinction between the Ahl-Kitab and Idol worshippers, atheists and polytheists is empirically evident from the Quran, which states:

They are not all alike; of the followers of the Book there is an upright party; they recite Allah's communications in the night time and they adore (Him). They believe in Allah and the last day, and they enjoin what is right and forbid the wrong, and they strive with one another in hastening to good deeds, and those are among the good. And whatever 
good they do, they shall not be denied it, and Allah knows those who guard (against evil). (As for) those who disbelieve, surely neither their wealth nor their children shall avail them in the least against Allah; and these are the inmates of the fire; therein they shall abide. ${ }^{60}$

\subsection{Interfaith Marriage between a Muslim Woman and a Non-Muslim Man}

Concerning whether Muslim women can marry outside of the Islamic faith, Islamic scholars ${ }^{61}$ cite the following Quranic verses:

Do not give (believing women) in marriage to idolaters until they believe, and certainly a believing servant is better than an idolater, even though he should please you. ${ }^{62}$

O you who believe! when believing women come to you flying, then examine them; Allah knows best their faith; then if you find them to be believing women, do not send them back to the unbelievers; neither are these (women) lawful for them, nor are those (men) lawful for them. ${ }^{63}$

The four Sunni Schools of jurisprudence are unanimous in agreeing that in this context a 'non-believer' refers to both the People of the Book and to idol worshippers, atheists and polytheists. ${ }^{64}$ Muslim women are therefore barred from marrying any non-Muslim man. But, and despite this consensus, not all Muslim scholars agree with this position, arguing instead that Muslim women can marry men from amongst the Ahl al-Kitab. ${ }^{65}$ The following section deals with the arguments.

The scholars who argue that Muslim women can marry from amongst the Ahl al-Kitab have made recourse to the fact that there is no provision in the Qur'an or Sunnah expressly prohibiting it. ${ }^{66}$ Moreover, they also appeal to the following Qur'anic statement: 'This day all good foods have been made lawful, and the food of those who were given the Scripture is lawful for you and your food is lawful for them. ${ }^{97}$ By analogy, they contend that, if the food of the $\mathrm{Ahl}$ al-Kitab is lawful for Muslims, so too should be marrying from amongst them. Scholars who maintain this view include Yohana, ${ }^{68}$ Lama, ${ }^{69}$ Lilian, ${ }^{70}$ Charles, ${ }^{71}$ and Alex. ${ }^{72}$

The opponents of Muslim women marrying from amongst the Ahl alKitab, on the other hand, and who include Muhammed, ${ }^{73}$ Zahidul, ${ }^{74}$ Abdullahi, ${ }^{75}$ Muhammad, ${ }^{76}$ Ambali, ${ }^{77}$ and Yusuf, ${ }^{78}$ have expressed their opinion in the context of a hadith related by Abu 'Abdullah al-Nu'man bin Bashir (RTA), who said:

I heard the Messenger of Allah (SWT) say: "The permissible (halal) is clear and the forbidden (haram) is clear, and between them are matters 
unclear that are unknown to most people. Whoever is wary of these unclear matters has absolved his religion and honor. And whoever indulges in them has indulged in the forbidden." who herds his sheep too close to a preserved sanctuary and they will eventually graze in it. Every king has a sanctuary, and the sanctuary of Allah is what He has made forbidden. There lies within the body a piece of flesh. If it is sound, the whole body is sound; and if it is corrupted, the whole body is corrupted. Verily this piece is the heart. ${ }^{80}$

This hadith is comprehensive, covering many aspects of the Shariah. Indeed, Imam al-Nawawi and many other scholars consider it to be one of the five hadith around which the entire religion of Islam is based ${ }^{81}$ This hadith indicates that all matters are one of three types: Halal (permissible), Haram (forbidden) or Doubtful.

Concerning the first of these, whatever Allah has made explicitly lawful in the Qur'an is a 'clear', permissible act. This includes only those acts about which there is no doubt. ${ }^{82}$ Turning to the forbidden, this is likewise whatever acts Allah has clearly established in the Islamic sources as forbidden. In the context of marriage, therefore, this would include the aforementioned passage from the Qur'an, 'Prohibited to you for marriage are your mothers, your daughters, your sisters, your father's sisters. ${ }^{83}$ Also: 'Do not give (believing women) in marriage to idolaters until they believe. ${ }^{94}$ Moreover, all matters Allah associates with punishment are included amongst the acts that are 'clearly' haram, such as evil lusts and desires, adultery/fornication, oppression or stealing. ${ }^{85}$ Concerning the third paradigm, or those acts considered to be doubtful, these are the most contentious and complex. They include acts which are neither explicitly permissible nor explicitly forbidden. ${ }^{86}$ These may be because scholars disagree about their permissibility (such as in the case of music) or because the acts themselves are a mixture of halal and haram. In this regard, the Prophet (SAW) says 'between the two of them are doubtful matters' and 'most people do not know them.' The implication is that Muslims should stay away from doubtful matters or else risk straying into what is haram. ${ }^{87}$

Given the above, although only the marriage of a Muslim woman to an idolater or polytheist is explicitly prohibited, because what is doubtful should be avoided, many scholars argue that it is better for a Muslim woman to also not marry a non-Muslim man who is from among the People of the Book. Indeed, although scholars differ about whether doubtful matters are permissible or forbidden, ${ }^{88}$ the popular opinion is that all doubtful matters are forbidden ${ }^{89}$ This opinion is supported by the aforementioned saying of the Prophet (SAW) that '...he clears himself in regard to his religion and his honor.' Another opinion, 
however, is that all doubtful matters are permissible. This position is also justified using an aforementioned saying of the Prophet (SAW), that '... [Allah] likes the shepherd who pastures around a sanctuary. ${ }^{90}$ This indicates that doubtful actions are permissible.

Reflecting on the above, while one may not declare outright whether a Muslim woman's marriage to a non-Muslim from the People of the Book is permissible or forbidden, the prevailing argument is that such interfaith marriages should be avoided. ${ }^{91}$ More importantly, the silence of the Qur'an regarding the right of a woman to marry a Christian/Jewish man can generally be interpreted to mean disapproval of such a union. ${ }^{92}$

\section{THE CHALLENGES OF INTERFAITH MARRIAGE}

Decisions relating to religion often cause the most intense types of trauma in Nigerian family life. Reactions to such decisions lead to changes that may cause separation in families. In particular, the journey towards an acceptance of interfaith marriage in Nigeria, if it occurs at all, may be long and arduous. Nevertheless, there has been an increase in interfaith marriages in Nigeria, especially among the Yorubas of the Western and Southern parts of the country. This is in part due to increased socialisation; as the world turns into a global village, making close contact between people of different faiths and traditions unavoidable, closer ties between groups, with the increased possibility of interfaith marriage, is inevitable. Moreover, in the past few decades, people from Nigeria have migrated in large numbers to developed countries in search of knowledge or financial stability. The vast majority of these men and women, originally from different towns, villages and language groups, have become more integrated, making interfaith marriage a natural (although still not easy) outcome.

The challenges associated with interfaith marriage are directly proportional to the differences in the backgrounds of couples, making the possibility of interfaith marriage failure very high. ${ }^{93}$ Differences in religion are not, however, the only potential difficulties facing couples involved in interfaith marriage. Other issues could include the following.

\subsection{Access to Religious Rights}

A concern for some scholars is that, if Muslim women marry outside their faith, they will lose their God-given rights because Islamic family law would no longer be able to address any issues that may arise, including in matters relating to divorce, child custody, and inheritance. ${ }^{94}$ 


\subsection{A Couple's Degree of Religiosity}

Interfaith couples will also face many qualitative challenges in their efforts to cultivate a religious environment in their homes - more so than a single-faith or single-cultural couple might typically encounter. ${ }^{95}$ This is because religious ideology is often strongly held; compromise on religion in interfaith marriages may therefore be difficult. Partners may have differing degrees of devotion to their religious heritage ${ }^{96}$ and this may either make or mar the friendly atmosphere of the family. ${ }^{97} \mathrm{~A}$ highly-devoted Muslim or non-Muslim may only accept an interfaith marriage on the condition that their partner abandon their own faith. If he/she accepts this request just for the sake of the marriage, the latter may eventually crumble.

Commitment to religion undoubtedly becomes difficult when partners are rigid and refuse to compromise on religious choice. ${ }^{98}$ In Nigeria, this may also impact on a child's choice of religion; a domineering party may foist his/her religion on a child. ${ }^{99}$

Moreover, when couples belong to different faiths, differing magnitudes of detachment between them and their spouse's family are formed. ${ }^{100}$ The resulting detachment will be especially pronounced when both spouses are strongly committed to their religious background and further exacerbated when couples have not given measured consideration to how their spiritual divergences will impact upon their marital and family stability. ${ }^{101}$

Gender roles, parenting issues, problem solving, closeness and/or distance to friends and relatives, and even an understanding of the purpose and meaning of marriage itself, may all be heavily influenced by religious difference and could contribute to conflict. ${ }^{102}$ It is critical that couples with different faiths explore each other's religious customs, values and beliefs to avoid emotional isolation and any situation capable of hindering fulfillment of either their or their family's needs. Even if an individual does not personally care about the religious faith of a potential spouse, the opinions and actions of parents, siblings, other kin, and friends can reduce the likelihood of a successful marriage. ${ }^{103}$

\subsection{Raising Children in a Religiously Diverse Family}

Many experts maintain that parents in an interfaith marriage find it difficult to raise children in association with just one place of worship; any decision to confine children to a single religion causes confusion, ${ }^{104}$ if not open confrontation, ${ }^{105}$ with all the potentially negative affects those things might have on a child. ${ }^{106}$ However, a child cannot be a Muslim, Christian, Traditionalist, or Jew all at the same time. As they are exposed to the different faiths and share in the rituals of those traditions, they need to know their own identity. 
Couples with a liberal attitude towards the practice of their religion may have less difficulty establishing religious and spiritual routines for their children. Moreover, children of interfaith marriages are often raised in the religious tradition of their mother because the latter is typically closer to them, constituting their first 'school'.${ }^{107}$ Addressing the potential conflicts when bringing up children in an interfaith environment therefore becomes the primary responsibility of the mother, while that of the father is significantly supplementary. Invariably, young children turn instinctively to their mothers rather than their fathers for nurture, comfort and security. The bond that nature forges between mother and child is characterised by far greater tenderness than that which is developed between father and child.

Prejudices relating to sex, race, religion, or caste are common in interfaith marriages. This and the challenges identified above explain the rationale behind opposition to interfaith marriages in multi-cultural and religiously divided societies like Nigeria, where they may become obstacles to the fulfillment of human unity.

\section{CONCLUSION}

It is concluded that, and notwithstanding the provisions of the Nigerian Constitution guaranteeing the individual right to marriage, Muslim women should not marry non-Muslim men. While the Shariah accepts the idea of inter-religious marriage between Muslim males and Jewish or Christian women, the case is more problematic for Muslim women. It is contended that, although there is nothing wrong with Muslims developing a humanistic approach to marriage, the difficulties inherent to interfaith marriage, and peculiarly within Nigerian society, make marriage between a Muslim woman and a non-believer unadvisable. As underscored by the commentary of Abdullah Yusuf Ali:

If religion is at all a real influence in life to both parties or to either party, a difference in this vital matter must affect the lives of both more profoundly than differences of birth, race, language or position in life. It is therefore only right that parties to be married should have the same spiritual outlook. If two parties love each other, their outlook in the highest things of life must be the same. ${ }^{108}$

Marriage provides emotional fulfillment and the promise of support in times of need. By bene $\neg$ fiting persons who choose to wed, marriage indirectly benefits society because persons who live in stable, fulfilling, and supportive relationships make better citizens. It is for these reasons, the argument goes, that a Muslim woman's right to enter into an interfaith marriage should be discouraged considering the challenges that may accompany it. 


\section{Notes}

* Ibrahim Imam is a Senior Lecturer, Department of Public Law, University of Ilorin, Ilorin, Nigeria; LLB, Umanu Danfodiyo University Sokoto, BL, Nigerian Law School, Abuja, LL.M, Obafemi Awolowo University, Ile-Ife, Ph.D., University of Ilorin, Ilorin, Nigeria. E-Mail: omotosho200620@yahoo.com GSM Nos: $+2348032277371$

1. See generally, Adamu, T., "The Need for Religious Co-existence" (2002), TCNN, Research Bulletin. No. 32, 12-23, Agi, S. P.I., Political History of Religious Violence in Nigeria, (Calabar, Ushie Printing \& Publishing, 1998), Coleman, J. S., Nigeria: Background to Nationalism, (University of California Press. Berkeley, 1963),

2. Ayinla S. A., Managing Religious Intolerance and Violence in Nigeria, Problems and Solutions, a Paper Presented at the National Conference on Social Problems, Development and the Challenges of Globalisation, Organised by Department of Sociology and Anthropology, Obafemi Awolowo University Ile-Ife (2003).

3. There are three Legal Systems recognized and operating in Nigeria, Common Law, Customary Law and Islamic Law, see also Ambali, "Islam and InterReligion Marriage", (Ilorin, Shebotimo Publications, 2010), 18.

4. Wali, A. B., "Marriage and Divorce in Islamic Law, in Judicial Lectures: Continuing Education for Judiciary", (Lagos, MIJ Professional Publisher Ltd, 1992), 17. see also MD Zahidul Islam, "Interfaith Marriage in Islam and Present Situation", GJPLR, 2 No. 1, (2014), 36-47, 37.

5. Quran: (4: 23-24).

6. Quran: (4: 22).

7. Zahidul Islam, "Interfaith Marriage in Islam and Present Situation", 37.

8. Vincent Cornell, "Voices of life: Family, Home and Society", (Nargis Viran Ltd, 2007).

9. Corinna Standke, "Shaia - The Islamic Law" (GRIN Veriage, 2008) and Kecia Ali, "Sexual Ethics and Islam, Feminist Reflections on the Quran, Hadith and Jurisprudence", (Oneword, 2006).

10. Charles Mwalimu, "The Nigerian Legal System: Public Law", (Lagos, Peter Lang, 2005) 673.

11. Dennis Robert, Islam: A Concise Introduction, (Harper \& Row, 1982) 143 and Talat Ara Ashraf, "Muslim Women in Changing Perspectives", (Commonwealth Publishers, 1992) 51.

12. Balkanlio M. A., "Influence of Alevi-Sunni Intermarriage on the Spouses' Religious Affiliation”, JISR, 4 No. 19 (2011), 298-315, 300.

13. Ambali, M. A., "The Practice of Islamic Family Law in Nigeria"; (Zaria, Tamaza Publishing Company Limited, 2003), 146.

14. Quran: (30: 21) see also A.B. Wali, Marriage and Divorce in Islamic Law, in "Judicial Lectures: Continuing Education for Judiciary", 34.

15. Yusuf Al-Qaradawi, "The Lawful and the Prohibited in Islam", (Lagos, AlTawheed Publishing Company, 1989), 177-178.

16. Abdur Rahman I. Doi, Shari'ah the Islamic Law, (UK: Ta'ha Publishers, 1990) $118-119$. 
17. Ibn Rushd, the Distinguished Jurist's Primer in Great Book of Islamic Civilization; Translated by Imran Ahsan and Reviewed by Muhammed Abdul Rauf (UK Garnet Publishing Ltd, 1996) $1-2$.

18. Quran 30 v 21.

19. Zahidul, "Interfaith Marriage in Islam and Present Situation”, 34.

20. Hamilton, C., "Family Law and Religion", (London, Sweet \& Maxwell, 2011), 66.

21. Ademola, A., "Customary Law and Doctrine of Repugnance Marriage in 1990"; Judicial Lectures: Continuing Education for the Judiciary, (Lagos, MIJ Professional Publishers Limited, 1982), 67-8.

22. Muhammad Hamidullahi, "Introduction to Islam", (London, MWH London Publishers, 1979) 138.

23. Pearl, D., and Menski, W., "Muslim Family Law”, (London, Sweet and Maxwell, 1998).

24. Yohanan, F., "Tolerance and Coercion in Islam: Interfaith Relation in Muslim Tradition", (Cambridge University Press, 2006), 161-175.

25. See generally, Barron, M. M., "The Blending of America: Patterns of Intermarriage", (Chicago Quadrangle Book, 1972), 212.

26. Krause H. D., \& Meyer, D. D., "What Family for the $21^{\text {st }}$ Century?", American JCL 50, (2002) 101, 103.

27. Chapter IV Constitution of Nigeria 1999 (as amended); Chapter 2 South African Constitution 1996, chapter 5 Ghana Constitution 1996, Chapter III Indian Constitution and Chapter III Malaysian Constitution.

28. Nigerian Constitution 1999 Chapter IV, s. 38.

29. The right marriage in some countries extends to same sex marriage. See; James Obergefell et al v Hodges, Director, Ohio Department of Health US 576 US 2583 (2015); In United States v Windsor 133 US 2683 (2013), and Baker v Nelson 409 U.S. 810 (1972).

30. Art. 1 Convention on Elimination of all Discrimination against Women, adopted and entered into force on 3 September 1981; see generally UN Human Rights Treaty System. An introduction to the core human rights treaties and the treaty bodies, fact sheet no 3, (UN, Geneva, 2005) see also Art 1(f) Protocol to the African Charter on Human and Peoples' Rights on the Rights of Women in Africa.

31. Art 16(1)-(3) UDHR.

32. Art 23(1)-(3) ICCPR.

33. Art 16(1)(a) \& (b) CEDAW.

34. Art 5(d)(iv) CERD.

35. See Bidmos M. A., "Inter-Religious Dialogue: the Nigerian Experience", (Islamic Publication Bureau, Lagos, 1993) 12, 27. Yahya O. I., "Religious Crises and Social Disruption in North-Eastern Nigeria", (Ibadan, Loud Book Publishers, 2004), 20-30.

36. The Nation, 29 November $2014 ; 1 \& 3$.

37. (Unreported) Suit No. HOS/M.17/2013, see also The Provost Kiara State College of Education, Ilorin vs. Bashirat Saliu \& Ors (Unreported) Suit No. CA/ IL/49/2006.

38. Yahya, "Religious Crises and Social Disruption in North-Eastern Nigeria," 2030. 
39. Ibid.

40. Christopher, L., (ed.), "Marriage between Christians and Muslims: Pastoral Guidelines for Christians and Churches in Europe", AJMMA, 20(1), (2000), 66.

41. Ambali, M. A., "Islam and Inter-Religious Marriage", 1; 13.

42. Ibid.

43. Piese, P. H., "Finding Meaning in Religious Practices: The Relationship between Holiday Rituals and Marital Satisfaction", JFP, (2001), 597-609.

44. Md. Zahidul-Islam, "Interfaith Marriage in Islam and Present Situation", 35.

45. Sunnah Ibn Majah; Book 11 No. 1859.

46. Roopnarine, J. L., and Gielen, U. P., (eds.), "Families in Global Perspective", (Boston: Pearson Education, 2005), 1-25.

47. Sahih Al-Bukhari, Vol. 7 Book 62, No. 27.

48. Larry, R. P., "Interfaith Marriage and Religious Commitment among Catholics", JFM, 48(4), (2005), 725-735.

49. Quran: (4: 144).

50. Quran: (60: 1).

51. Glasse, C., "The Encyclopedia of Islam," (NY., Al-Hemira Press, 1989), 247.

52. Alex, "Interfaith Marriage in Islam: An Examination of Legal Theory Behind Traditions and Reformists Position", 747.

53. Quran: (2: 221).

54. Quran: (5: 5).

55. Quran: (60: 10).

56. Wali, "Marriage and Divorce in Islamic Law", He posits that a Muslim can marry a woman because of her family lineage, religion, status, piety, wealth, financial means such as property, trade or craft.

57. Quran: (2: 285).

58. See generally, Uthman, M., "The Law of Marriage in Islam", (London: Da' al Taqwa, 1995), 56

59. Quran: (3: 113-116).

60. Ibid.

61. See generally, Javai, D. R., "The Shariah, Islamic Family Laws and International Human Rights Law: Examining the Theory and Practice of Polygamy and Talaq", IJLPF, 21(1), (2007), 55.

62. Quran: $(2: 221)$.

63. Quran: (60: 10).

64. An-Naim, A. A., (ed.), "Islamic Family Law in a Changing World: A Global Resource Book", (London, Zed Books Limited, 2002), 2-21.

65. Yusuf Al-Qaradawi, "The Lawful and Prohibited in Islam", 183-184.

66. Ibid.

67. Quran: (5: 5).

68. Yaohana Friedman, "Women and Gender in Islam: Historical Root of a Modern Debate”, (New Haven, London, 1992).

69. Lama Abu_Odeh, "Modernizing Muslim Family Law: The Case of Egypt", Vanderbitt Journal of Transnational Law,37, (2007) 1048-11146.

70. Lilian Edwards and Anne M. O. G., "Muslim Family Law", (Edinburgh University Press, 2006), 349.

71. Charlese Tylor, "Multiculturalism and 'the Politics of Recognition", (London, 
Princeton Press, 1992).

72. Alex B. L., "Interfaith Marriage in Islam: An Examination of the Legal Theory Behind Traditional and Reformist", Indian Law Journal 8, (2009).

73. Muhammad Z. K., Islam and Human Rights (5 ${ }^{\text {th }}$ ed., International Publication Ltd., 1999) 37.

74. Zahidul, Interfaith Marriage in Islam: Present Situation, 18.

75. Abdullahi Ibn Hassan Al-Kashinawiyi, Ashalul Madarik Sharh Ir-Shad Sslik (Darul Fikr, Lebanon, 1976), 92.

76. Muhammad Ali As-Sayisi, Tafsir Ayatul Ahkam (Muhammad Ali Sahib Press, 1986) 226.

77. Ambali M. A., Islam and Inter-Religious Marriage.

78. Islam and Human Rights (5 ${ }^{\text {th }}$ ed., International Publication Ltd., 1999) 37.

79. Kamali, Mohammed Hashim, "Principles of Islamic Jurisprudence", (London, Cambridge Islamic Text Society, 1991), 168-188.

80. Bukhari and Muslim, Vol. 66 Book 7 No. 55.

81. Kamali, "Principles of Islamic Jurisprudence", 170, see also Keller et al; "Encyclopedia of Women and Religion in North America", (Indiana University Press, India, 2010), 224-226.

82. Quran: (2: 221).

83. Quran: (4: 23).

84. Quran: (2: 221).

85. Doi, A. R., and Begley, A., "Women in Shariah", (London, Ta Ha Publishers, 1992), 64.

86. Bard, G. M., "Islamic law: Its Relations to other Legal Systems", AJCL 26, (1978), 187-98 and Nassir, J. J., "The Islamic Law of Personal Status", (London, Graham and Trot man, 1990).

87. Afshari, R., "An Essay on Islamic Cultural Relativism in the Discourse of Human Rights", $H R Q, 16$, (1994), 235-76.

88. BF Stowasser, B. F., "Women in Quran, Tradition and Interpretation", (London, Oxford, University Press, 1884), 77-79.

89. Abbott, N., "Women and State in the Early Islam", JNES, United State, 1(3), (1942), 341-368.

90. Alex, "Interfaith Marriage in Islam: An Examination of Legal Theory behind Tradition and Reformists Position" 733.

91. S. T. Abdullah, Marriage with Jews and Christians, Islamic Voice, June 1997, http://islamicvoice.com/june.97/dialogue.htm\#CHR> accessed, 10 November 2014.

92. Yusuf al-Qaradawi, "The Lawful and Prohibited in Islam”, 183.

93. Eaton, S. C., "Marriage between Jews and non-Jews: Counseling Implications", $J M C D, 22$ No. 4, (1994), 210-214, Joanides, C. M., et al, 'Investigating InterChristian and Intercultural Couples Associated with the Greek Orthodox Archdiocese of America': Qualitative Research Project'; AJFT, 30, (2002), 373383.

94. Courtney, P. E., "Reconciling Conflicting Identity: How National and Religious Identities Influences the Decision to Marry in Egypt", Sacha JSJ, 3 No. 1, (2005), 675-686.

95. Fiese, B. H., 'Finding Meaning in Religious Practices: the Relation between 
Religious Holiday, Rituals and Marital Satisfaction', JFP, (2001), 597-609.

96. Adam, B. S., 'Tolerance, Tradition and Modernity", Cardozo LR, 24, (2003), $1645-1652$.

97. Horowiiz, J. A., 'Negotiating Couplehood: the Process of Resolving the Dilemma among Interfaith Couples', 38 No. 3, (1999), 311-312.

98. Md. Zahidul Islam, "Interfaith Marriage in Islam and Present Situation" 33.

99. Ibid.

100. Becvar, D. S., \& Becvar, R. J., "Family therapy: A Systemic Integration", (Boston: Allyn and Bacon, 2003)

101. Ibid.

102. Ibid.

103. DE Sherkat, "Religious Intermarriage in the United State: Trends Patterns, and Predictors", SJR, 33, (2004), 606-625, 610.

104. Larry, "Interfaith Marriage and Religious Commitment among Catholics" 56.

105. Chinitz, J. G., and Brown, R. A., 'Religious Homogeny, Marital Conflict, and Stability in Same-Faith and Interfaith Jewish Marriages', JSSR, 40 No. 4, (2001), 723-733.

106. LM Sussman, 'How Religiosity and Ethnicity Affect Marital Satisfaction for Jewish-Christian Couples', JMHC, 21, (2), (1999), 73-185.

107. Ibid.

108. Abdullah, Yusuf Ali, "The Holy Quran". (Brentwood: MD: Amana Corporation, 1989), 25. 